\title{
REACTIVE AND NON-REACTIVE TRACE GAS EXCHANGE WITHIN AND ABOVE AN AMAZONIAN RAINFOREST
}

\author{
Stefan Aiko Wolff ${ }^{1,2,}$, Ivonne Trebs ${ }^{2}$, Antonio Ocimar Manzi ${ }^{1}$, \\ Leonardo Deane de Abreu Sá ${ }^{3}$ \\ ${ }^{1}$ Instituto Nacional de Pesquisas da Amazônia/ INPA - Manaus, AM \\ ${ }^{2}$ Biogeochemistry Department, Max Planck Institute for Chemistry - Mainz, Germany \\ 3Instituto Nacional de Pesquisas Espaciais - Belém, PA \\ *stefan.wolff@mpic.de
}

\begin{abstract}
In 2011 the currently highest atmospheric research tower of Amazonia was erected at the ATTO site $\left(02^{\circ} 08^{\prime} 38,8^{\prime \prime} \mathrm{S}, 58^{\circ} 59^{\prime} 59,5^{\prime}\right.$ 'W) (whereas ATTO stands for Amazon Tall Tower Observatory), which is monitoring concentration gradients regarding 5 trace gases $\left(\mathrm{H}_{2} \mathrm{O}\right.$, $\mathrm{CO}_{2}, \mathrm{O}_{3}, \mathrm{NO}, \mathrm{NO}_{2}$ ) from 8 different heights between $0,05 \mathrm{~m}$ and 79,3 $\mathrm{m}$, which enables the possibility to get new results regarding transport processes in and above the canopy. Never before there have been made profile measurements up to that height in the Amazonian rainforest.
\end{abstract}

\section{RESUMO}

Em 2011, a torre mais alta de toda Amazônia foi erguida no sitio ATTO (Amazon Tall Tower Observatory) $\left(02^{\circ} 08^{\prime} 38,8^{\prime} ’ \mathrm{~S}, 58^{\circ} 59^{\prime} 59,5^{\prime} \mathrm{W}\right)$, com a finalidade de se fazer medidas atmosféricas. Nessa pesquisa estão sendo monitoradas as concentrações de 5 gases traços $\left(\mathrm{H}_{2} \mathrm{O}, \mathrm{CO}_{2}, \mathrm{O}_{3}, \mathrm{NO}, \mathrm{NO}_{2}\right)$, em 8 níveis diferentes, entre 0,05 e 79,3 metros. Isso possibilitará encontrar novos resultados relacionados a processos de transporte dentro e acima do dossel. Até agora não foram feitas medidas de perfilamento até estas alturas na floresta Amazônica. 


\section{INTRODUCTION}

Emissions of gases with lifetimes shorter than the transport time from their source to a measurement site can't be detected anymore at that site, so the further a place is away from (anthropogenic) trace gas sources, the less of those substances the atmosphere contains there. The inner Amazonia is one of the last places on earth where some reactive trace gas concentrations still exhibit preindustrial levels.

Ozone $\left(\mathrm{O}_{3}\right)$ plays a central role regarding chemical reactions within the $\mathrm{NO}-\mathrm{NO}_{2}-\mathrm{O}_{3}$ triad and within many further oxidation processes including different trace gases and various surfaces. Naturally produced mainly inside the stratosphere, the tropospheric $\mathrm{O}_{3-}$ concentrations are strongly influenced by anthropogenic $\mathrm{NO}_{\mathrm{x}}$-emissions. In the inner Amazonia studies in nearly natural $\mathrm{O}_{3}$-concentrations can lead to a deeper understanding of trace gas transports, deposition and subsequent (environmental) effects.

Related to transport processes from the higher troposphere and even the lower stratosphere until ground levels, downdraft events could exhibit a specific role. It has been detected some distinctive nighttime increase in $\mathrm{O}_{3}$-levels due to downward transports during the Wet Season Atmospheric Mesoscale Campaign (WETAMC) in Ouro Preto d'Oeste in Rondonia [Betts, 2002]. One objective of this research is the detection and analysis of similar events at the ATTO site. Due to different topographic properties and meteorological regimes between the two regions, distinctive differences regarding vertical atmospheric transport processes are expected.

\section{MATERIALS AND METHODS}

Figure 1 displays an overview of the gradient system, containning 3 trace gas analyzers, inlets, pumps, valve block and data storage unit as well as a heated tube system. Additionally there was installed a drying unit, which avoids effects due to humidity oscillations. 


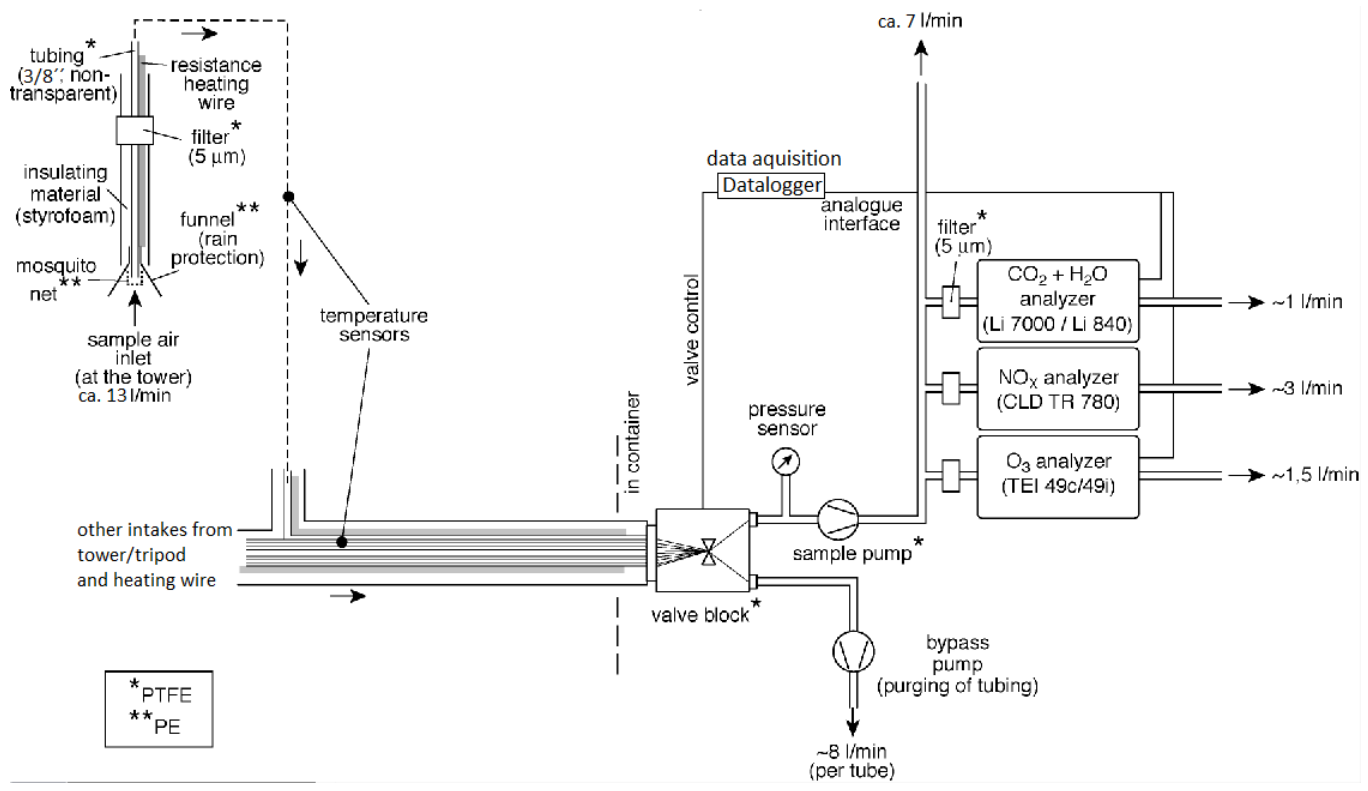

Fig. 1: Profile system with inlets and analyzers [courtesy of A. Moravek]

\section{FIRST RESULTS}

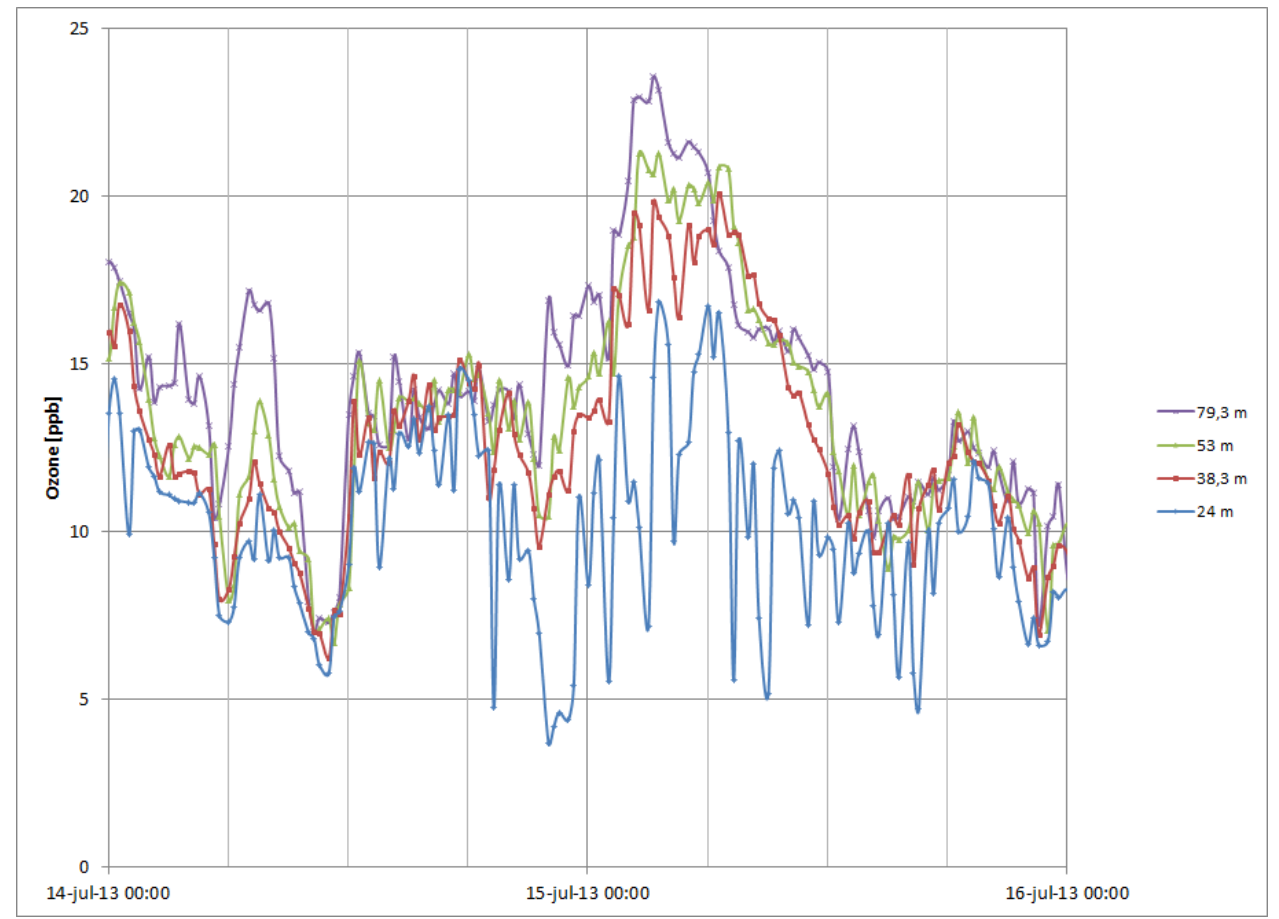

Fig. 2: Ozone profile at the ATTO-site between 14/07/13 and 16/07/13 
Figure 2 displays an example for a nighttime increase in $\mathrm{O}_{3}$-concentrations especially above the canopy. Those events will be analyzed in detail with the help of various further parameters like equivalent potential temperature $\theta_{e}$, flux data and meteorological measurements.

\section{CONCLUSIONS}

The first results already represent $\mathrm{O}_{3}$-gradients and courses including several nighttime increases which will be analyzed concerning strong vertical transport processes and effects.

\section{ACKNOWLEDGEMENTS}

I gratefully acknowledge the support by the Coordenação de Aperfeiçoamento de Pessoal de Nivel Superior (CAPES) and by the Max Planck Society for all the instrumental, scientific, logistical and personal help. I thank especially my supervisor Prof. Dr. Antonio O. Manzi, my Co-supervisors Dr. Ivonne Trebs and Prof. Dr. Leonardo Sá, the whole research group of Dr. Ivonne Trebs, and the technical team of INPA which strongly supports the installations, the data generation and its transfer as well as the alimentation and the quality of life at the ATTO-site.

\section{REFERENCES}

Andreae,M.O.et al. Biogeochemical cycling of carbon, water, energy, trace gases, and aerosols in Amazonia. Journ.of Geophys. Res., 107, D20: 33: 1-25. 2002.

Betts,A.K.et al. Transport of ozone to surface by convective down-drafts at night. Journ.of Geophys. Research, VOL.107, No. D20, 8046. 2002.

Browell, E.V.; Gregory, G.L. \& Harriss, R.C. Tropospheric Ozone and Aerosol Distributions Across the Amazon Basin. Journ.of Geophys. Res., Vol. 93, NO. D2, pp 1431-1451. 1988. 